\title{
UK Sale of Goods Legislation 1893-2015: Towards Plain(er) Language?
}

L'évolution du style des textes législatifs au Royaume-Uni portant sur la vente des biens (1893-2015)

\section{Simon Taylor}

\section{OpenEdition}

\section{Journals}

Electronic version

URL: http://journals.openedition.org/asp/5411

DOI: 10.4000/asp.5411

ISSN: 2108-6354

\section{Publisher}

Groupe d'étude et de recherche en anglais de spécialité

\section{Printed version}

Date of publication: 1 November 2018

Number of pages: $95-112$

ISSN: 1246-8185

\section{Electronic reference}

Simon Taylor, «UK Sale of Goods Legislation 1893-2015: Towards Plain(er) Language? », ASp [Online], 74 | 2018, Online since 01 November 2019, connection on 10 December 2020. URL : http:// journals.openedition.org/asp/5411; DOI : https://doi.org/10.4000/asp.5411

This text was automatically generated on 10 December 2020.

Tous droits réservés 


\section{UK Sale of Goods Legislation 1893-2015: Towards Plain(er)}

\section{Language?}

L'évolution du style des textes législatifs au Royaume-Uni portant sur la vente

des biens (1893-2015)

Simon Taylor

\section{Introduction}

1 The aim of this article is to discuss whether, through a diachronic study of UK sale of goods legislation, we can detect an evolution in legislative style. If so, what is the nature of this evolution, and to what extent has any change in style been influenced by the Plain Language Movement?

2 The first general sale of goods legislation was introduced into UK ${ }^{1}$ law in the form of the Sale of Goods Act 1893. This legislation has undergone a number of modifications since then. We will focus on the original Act and on three subsequent Acts: the Sale of Goods Act 1979, the Sale and Supply of Goods Act 1994 and most recently the Consumer Protection Act 2015. These Acts, more than others in the same field, ${ }^{2}$ introduce significant stylistic as well as substantive changes. Within this legislation, we concentrate on the specific example of the provisions relating to implied contractual terms about the quality of the goods sold or supplied. These provisions give significant protection for the purchaser of goods since they state that all sale of goods contracts include, whether expressly or by implication, a term guaranteeing that the goods have a minimum level of quality. Should there be a breach of this term, the buyer will have the right to terminate the contract, reject the goods and seek damages. The 2015 legislation attributes further remedial rights to a purchaser who qualifies as a "consumer"3 under that legislation. 
3 The legislative provisions relating to the quality of goods provide a particularly apposite subject of study since the fundamental rules on implied terms about quality have not evolved significantly since the initial enactment in 1893 . This makes it easier for us to note changes in the legislative style where the purpose is to render the English plainer rather than to modify the substantive rules themselves, and we shall see that legislative style has in fact evolved to a significant extent.

\section{The traditional legislative style for UK legislation}

The legislative style of UK legislation has been subject to considerable criticism over the years on the grounds of its complexity. UK legislation is drafted centrally by an office under government control, the Office of Parliamentary Counsel, established in 1869. Traditionally, draftsmen try to reduce ambiguities in legislation to a minimum ${ }^{4}$ and to cater for a maximum of eventualities. The consequence is a legislative style that is technical, somewhat verbose and detailed, ${ }^{5}$ multiplying examples and exceptions. The legislation is often syntactically complex, over-elaborate and difficult to read. This critical view was shared by the Renton Committee, which submitted its report on the drafting of UK legislation to Parliament in 1975. ${ }^{6}$ Despite the criticism contained in the Committee's report, and the support for the Committee's findings expressed in the subsequent House of Lords debate on the question ((HL Deb 10 Dec. 1975, vol.366, cc 945-1038), no obvious reform of English legislative style followed.

5 Nevertheless, the fact that the government commissioned the Renton Committee's report revealed a concern for the quality of legislative drafting. The increasing awareness of the need for plainer language formed part of a substantial movement and reflection on this subject since the 1960s by both linguists and lawyers which will be well known to readers. ${ }^{7}$ However, an interest in improving legislative style can be traced to much earlier times. Edward VI is reported to have said in the 16th century "I wish that the superfluous and tedious statutes were brought into one sum together, and made more plain and short" (Renton 1978: 7; also cited in Office of Parliamentary Counsel 2013: 3). In 1875 a UK parliamentary select committee was appointed to consider "whether any and what means can be adopted to improve the manner and language of current legislation" although Renton described their mild criticism of drafting style as "remarkably complacent" (1978: 8). The question of how to write UK legislation in plainer English remains of clear concern today. The office of Parliamentary Counsel published a report in 2008 recommending a reduction in the use of "shall" in legislative drafting (Office of Parliamentary Counsel [2008]; see on this Williams [2011: 142-143)]. In a report published in 2013, Parliamentary Counsel recognised that they "have adopted a plain English style which would have been unrecognisable in their 1970s predecessors" (Office of Parliamentary Counsel [2013: 3]).

An evolution in legislative style towards plainer English is apparent from a diachronic analysis of our corpus. 


\section{A diachronic analysis of Sale of Goods legislation}

\subsection{The Sale of Goods Act 1893}

7 The Sale of Goods Act 1893 is essentially a codification of rules derived from earlier case law, and the cases from which the Act is derived are almost always disputes between merchants. The legislation has thus been described as "essentially a nineteenth century mercantile code" (Law Commission and Scottish Law Commission 1987: 2) and the idea of consumer law in its modern form was not officially recognised by the legislator until a report of the Committee on Consumer Protection (1962). As legislation was destined to apply to contracts between experienced merchants, plain English was not perceived as an objective, as can be seen from a reading of section 14 of the 1893 Act:

14. Implied conditions as to quality or fitness

Subject to the provisions of this Act and of any statute in that behalf, there is no implied warranty or condition as to the quality or fitness for any particular purpose of goods supplied under a contract of sale, except as follows:-

(1) Where the buyer, expressly or by implication, makes known to the seller the particular purpose for which the goods are required, so as to show that the buyer relies on the seller's skill or judgment, and the goods are of a description which it is in the course of the seller's business to supply (whether he be the manufacturer or not), there is an implied condition that the goods shall be reasonably fit for such purpose, provided that in the case of a contract for the sale of a specified article under its patent or other trade name, there is no implied condition as to its fitness for any particular purpose:

(2) Where goods are bought by description from a seller who deals in goods of that description (whether he be the manufacturer or not), there is an implied condition that the goods shall be of merchantable quality; provided that if the buyer has examined the goods, there shall be no implied condition as regards defects which such examination ought to have revealed:

(3) An implied warranty or condition as to quality or fitness for a particular purpose may be annexed by the usage of trade:

(4) An express warranty or condition does not negative a warranty or condition implied by this Act unless inconsistent therewith.

The legislation contains a number of examples of complex syntax, lengthy sentences and technical terms that render comprehension difficult. Indeed, the whole section of 259 words is actually one sentence. Section 14 is front-loaded with a condition ("subject to..." $)^{8}$ and the provision is expressed in the negative, with the main rule that there is an implied term of fitness and quality in sale of goods contracts expressed as an exception to a rule that no such term is included in contracts. Within the exception, there are a large number of qualifying phrases. In addition, a number of the terms used are of a technical nature. The term "condition" and "warranty" are technical terms. ${ }^{9}$ One of the key concepts introduced by the provisions is that of "merchantable quality". The meaning of "merchantable" is not immediately apparent from the legislation and no definition of the concept is provided. A leading commentator on sale of goods law has observed that “[T]he expression 'merchantable quality' is and always has been a commercial man's notion: this explains why the original Act did not define it commercial juries needed no direction on how to make the appropriate findings." (Benjamin \& Guest 1981: para 800).

9 Despite the evident complexity of the text, nevertheless some effort was made by its drafters to facilitate access for readers. Thus, in the extract, as with the remainder of 
the Act, the various sections have headings and the section and sub-sections are numbered. Section headings were not a recent phenomenon. Jeremy Bentham (1843: 240) and Arthur Symonds (Horn 2011: 189) argued the benefits of headings to improve understanding of legislation. Horn describes how Sir Henry Thring, the first Chief Parliamentary Counsel, appointed in 1869, set out a certain number of drafting principles in the interests of plain English (2011: 189). One of these was the use of headings that should provide "a tolerably accurate idea of the contents of the Act." He first introduced the modern technique of breaking up Acts into parts, and sections into subsections in the 1854 Merchant Shipping Act (Watson-Brown 2009: 89). We can see this principle being put into operation in section 14 of the 1893 Sale of Goods Act.

Despite a growing concern to develop consumer protection law which was first officially expressed in the Report of the Committee on Consumer Protection in 1962, the next Act in this area, the Supply of Goods (Implied Terms) Act 1973, consisted simply of minor modifications to the 1893 text by a process of "patching," 10 simply adding precision to the 1893 Act on substantive legal points without any attempt at facilitating access. It is notable that in the parliamentary debates concerning the 1973 enactment no reference was made to the need for plain English. Lord Airedale, during the debates on the legislation in the House of Lords, observed that the Bill was "riddled with technicalities" (HL Deb 1972: para. 855). Baroness Phillips (idem. para. 851) described the Bill as "basically a lawyer's Bill."

11 More significant stylistic change was however introduced by the Sale of Goods Act 1979. If we consider that interest in developing plainer language increased from the 1970s in the UK, as evidenced by the Renton report and by articles critical of the English legislative style written by William Dale $(1977,1985,1992)$, then it is interesting to compare how the legislative style evolved between 1893 and 1979.

\subsection{The Sale of Goods Act 1979}

The 1979 Act was presented by its promoters as a consolidation of amendments made to the original 1893 Act. No mention was made in the parliamentary debates ${ }^{11}$ of any need to make stylistic changes to render the text more accessible. However, a comparison of the 1893 provisions on the quality of goods with those of the 1979 Act reveals that there was nevertheless some effort in the legislative drafting of the later Act to facilitate access to the rules, although the 1979 Act retains a marked degree of stylistic complexity, particular with respect to sentence structure.

Implied terms about quality or fitness

14 (1) Except as provided by this section and section 15 below and subject to any other enactment, there is no implied condition or warranty about the quality or fitness for any particular purpose of goods supplied under a contract of sale.

(2) Where the seller sells goods in the course of a business there is an implied condition that the good supplied under the contract are of merchantable quality, except that there is no such condition-

(a) as regards defects specifically drawn to the buyer's attention before the contract is made; or

(b) if the buyer examines the goods before the contract is made, as regards defects which that examination ought to reveal.

(3) Where the seller sells goods in the course of a business and the buyer, expressly or by implication, makes known-

(a) to the seller, or 
(b) where the purchase price or part of it is payable by instalments and the goods were previously sold by a creditbroker to the seller, to that creditbroker, any particular purpose for which the goods are being bought, there is an implied condition that the goods supplied under the contract are reasonably fit for that purpose, whether or not that is a purpose for which such goods are commonly supplied, except where the circumstances show that the buyer does not rely, or that it is unreasonable for him to rely, on the skill or judgment of the seller or creditbroker.

[...]

(6) Goods of any kind are of merchantable quality within the meaning of subsection

(2) above if they are as fit for the purpose or purposes for which goods of that kind are commonly bought as it is reasonable to expect having regard to any description of them, including the price if relevant and all the other relevant circumstances.

[...] words as opposed to 259 words for the 1893 Act. This is due to the fact that the more recent legislation adds substantive rules and is not due to any increase in stylistic complexity as such. The 1979 Act still front-loads the opening paragraph of section 14 with an exception. Nevertheless, there is a simplified sentence structure here compared to the earlier legislation. Thus, whereas the 1893 starts with reference to an exception "subject to 覧...医" and then finishes the opening phrase with a second exception ".... except as follows", the 1979 Act avoids this added complexity by dealing with the exceptions together in the opening phrase: "Except as provided by this section

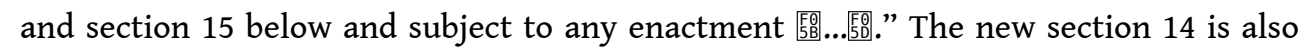
broken down into several sentences. The central concept of "merchantable quality" is defined in the 1979 Act, ${ }^{12}$ whereas no definition was provided in the 1893 Act. sub-paragraphs to facilitate comprehension. This is certainly not systematic, but an example can be found in section 14(2), where the Act mentions two situations where no implied term of merchantable quality will be implied. However, despite the provision being broken down in part, it still remains structurally complex since it attempts to deal with multiple exceptions to the rule within the same sentence.

There are also some changes in the terms and wording used in the 1979 text compared to the 1893 provisions. Thus, whereas the heading to the 1893 text refers to "implied conditions as to quality", the 1979 version refers to "implied conditions about quality". The 1979 Act also changes the passive voice to the active: "where goods are bought

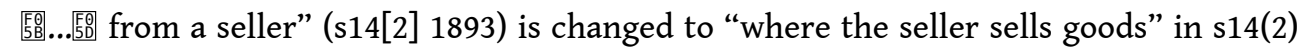
of the 1979 version. In the same subsection, the obligation of merchantable quality expressed in 1893 by "shall be" is changed to "are of" merchantable quality in the 1979 Act. Some simplification is also provided by changing verbs in the present perfect to verbs in the present tense: hence, reference to defects which "examination ought to have revealed" (s14[2] 1893) is changed to defects which "examination ought to reveal" (s14[2](b) 1979).

The examples provided here are all purely stylistic changes that do not change the substantive content of the rules. We can conjecture that Parliamentary Counsel drafting the 1979 Act made these changes with a desire to improve the clarity of the rules. However, there is clearly still considerable progress to be made, as evidenced, for example, by the wording of s14(3): 
Where the seller sells goods in the course of a business and the buyer, expressly or by implication makes known-
(a) to the seller, or
(b) where the purchase price or part of it is payable by instalments and the goods were previously sold by a creditbroker to the seller, to that creditbroker,
any particular purpose for which the goods are being bought, there is an implied condition that the goods supplied under the contract are reasonably fit for that purpose, whether or not that is a purpose for which such goods are commonly supplied, except where the circumstances show that the buyer does not rely, or that it is unreasonable for him to rely, on the skill or judgment of the seller or creditbroker.

The difficulty in this section is that there is information overload: it is attempting to deal with too many situations at once. It would thus have been simpler to have separate sections dealing with the position of sellers and credit brokers. The section also includes reference to a number of exceptions, thus making the syntax extremely complex, whereas these exceptions could have been considered in a separate section.

\subsection{The Sale and Supply of Goods Act 1994}

The Sale and Supply of Goods Act 1994 was enacted to introduce certain substantive amendments to the Sale of Goods Act $1979 .{ }^{13}$ For our purposes the 1994 Act is significant since it contributes in a very noticeable way to providing a plainer version of the 1979 Act.

The Act changes the implied contractual term of "merchantable quality" to one of "satisfactory quality", following heavy criticism by the Law Commission of the former term. The Law Commission observed that "if the word 'merchantable' has any real meaning today, it must strictly be a meaning that relates to merchants and trade: the word must be inappropriate in the context of a consumer transaction." (1987: para. 2.10). However, the debate surrounding replacement of the term did not focus on the obvious lack of accessibility of the term for the non-lawyer but on the need for a term which would more closely reflect the substantive legal requirements as to the quality of goods sold. The term "good" quality was deemed inappropriate since it would not cover goods sold as rejects or scrap, the terms "suitable" and "proper" were considered meaningless without further definition (idem: para. 3.12). Finally, "satisfactory" was preferred to "acceptable" since it was thought a reluctant buyer might find the goods acceptable whilst they were not "satisfactory". Hence, the term "satisfactory" can be seen as being chosen because it increased the substantive protection of the buyer, without the "plainer" nature of the term being given as a reason for the change.

However, other changes were clearly intended to add to the stylistic as well as the substantive clarity of the text. Thus, amendments made to section 14(2) of the Sale of Goods Act 1979 provide explanations as to what is meant by "satisfactory quality" and "quality" in this context. Noticeably, the examples are provided in list form, with significant spacing between the different examples to help the reader.

(1) Except as provided by this section and section 15 below and subject to any other enactment, there is no implied term about the quality or fitness for any particular purpose of goods supplied under a contract of sale.

(2) Where the seller sells goods in the course of a business, there is an implied term that the goods supplied under the contract are of satisfactory quality.

(2A) For the purposes of this Act, goods are of satisfactory quality if they meet the standard that a reasonable person would regard as satisfactory, taking account of 
any description of the goods, the price (if relevant) and all the other relevant circumstances.

(2B) For the purposes of this Act, the quality of goods includes their state and condition and the following (among others) are in appropriate cases aspects of the quality of goods-

(a) fitness for all the purposes for which goods of the kind in question are commonly supplied,

(b) appearance and finish,

(c) freedom from minor defects,

(d) safety, and

(e) durability.

(2C) The term implied by subsection (2) above does not extend to any matter making the quality of goods unsatisfactory-

(a) which is specifically drawn to the buyer's attention before the contract is made,

(b) where the buyer examines the goods before the contract is made, which that examination ought to reveal, or

(c) in the case of a contract for sale by sample, which would have been apparent on a reasonable examination of the sample.

Also of note here is the fact that the exceptions to the rule are now stated in the separate paragraph $2 \mathrm{C}$, thus enabling the overall structure of sub-section 14(2) to be simplified by a far less complex syntax. The opening sub-section 14(1) is still however front-loaded by rule expressed in the negative.

\subsection{The Consumer Rights Act 2015}

Whereas the previous legislation applied to both business to business ("B2B") and business to consumer ("B2C") transactions, the Consumer Rights Act 2015 only covers consumer rights in sales from a business. The Sale of Goods Act 1979, as amended by subsequent legislation, remains applicable to B2B sales. The Consumer Rights Act was introduced principally in order to consolidate in one place various pieces of consumer protection legislation of both domestic and European origin. Since it concerns the rights of consumers rather than of experienced business parties, it might therefore be expected to create the ideal context for an extended use of plain language techniques. Certainly, the explanatory notes to the Act would suggest that one of its aims was to provide more accessible language. Thus, in the opening paragraph of those notes setting the context, it is stated that:

There is general agreement across business and consumer groups that the existing UK consumer law is unnecessarily complex. It is fragmented and, in places, unclear, for example where the law has not kept up with technological change or lacks precision or where it is couched in legalistic language. notes make clear that expressing the rules in less legalistic language is a significant goal.

9 Goods to be of satisfactory quality

(1) Every contract to supply goods is to be treated as including a term that the quality of the goods is satisfactory.

(2) The quality of goods is satisfactory if they meet the standard that a reasonable person would consider satisfactory, taking account of-

(a) any description of the goods,

(b) the price or other consideration for the goods (if relevant), and

(c) all the other relevant circumstances (see subsection (5)). 
(3) The quality of goods includes their state and condition; and the following aspects (among others) are in appropriate cases aspects of the quality of goods-

(a) fitness for all the purposes for which goods of that kind are usually supplied;

(b) appearance and finish;

(c) freedom from minor defects;

(d) safety;

(e) durability.

(4) The term mentioned in subsection (1) does not cover anything which makes the quality of the goods unsatisfactory-

(a) which is specifically drawn to the consumer's attention before the contract is made,

(b) where the consumer examines the goods before the contract is made, which that examination ought to reveal, or

(c) in the case of a contract to supply goods by sample, which would have been apparent on a reasonable examination of the sample.

[...]

The 2015 legislation continues the work of the 1994 Act by adding further clarity to the provisions. Section 9 (1) of the Consumer Rights Act presents a very clear basic rule ("Every contract to supply goods is to be treated as including a term that the quality of the goods is satisfactory"), in striking contrast to the sections with front-loaded exceptions in the previous legislation. Reference to "implied terms" is replaced by a statement that contracts are "treated as including" a term on quality. This change is intended to make the idea easier to understand for the consumer for whom the notion of an "implied term" is potentially obscure (Department of Business Innovation and Skills 2012: para. 5.66).

The Act then follows with explanations of what is meant by "satisfactory" and "quality", and these explanations are presented by way of examples in list form, as in the 1994 Act. The redundant phrase "for the purposes of this Act" in 2A and 2B of the amended 1979 Act has been removed from the start of each sub-section. Again, as in the 1994 Act, the exceptions to the rule are provided at the end, as a separate sub-section.

An additional noticeable innovation is with respect to the section headings and headings to significant parts of the Act. In the 1979 Act, for the part of the Act dealing with implied terms, the heading was "Conditions and Warranties". As we have observed, these are both technical legal terms. This heading is replaced in the Consumer Rights Act with "What statutory rights are there under a goods contract?" This heading is clearly aimed at facilitating the reading of the provisions. Headings in the form of questions are argued to create a greater sense of immediacy, engaging the reader in a dialogue (Horn 2011: 202). Empirical evidence indicates that this technique facilitates understanding of legislation amongst readers (idem.) The headings to the specific sections on terms as to quality have also been changed. "Implied terms about quality" is replaced by "Goods to be of satisfactory quality" and "Goods to be fit for particular purpose". Headings indicating content have thus been replaced by headings summarising the rules. They introduce an element of redundancy that is argued to help understanding: when complex material is presented, repetition of what is new is used as a communication tool (Sullivan 2001: 154). 


\section{Towards plain(er) English: easification or simplification?} studied. This is most apparent from 1994, although signs of a concern for "plainer" English can be observed in the 1979 legislation. However, ease of access and "plain language" were only specifically voiced by reformers as one of the reasons for amendments with respect to the 2015 Act. Nevertheless, despite the lack of specific acknowledgment of a policy of plain language in the earlier legislation, we can conjecture that changes in style occurred as a result of the general drafting policy of Parliamentary Counsel to adopt certain precepts of the Plain Language Movement. Indeed, this has been specifically recognised by Parliamentary Counsel themselves. In an answer to the House of Commons Political and Constitutional Reform Committee enquiry into ensuring standards in the quality of legislation, witnesses from the office of Parliamentary Counsel stated that the Office has worked to make legislation more accessible, has focused on plain language techniques to institute changes to the formatting of legislation, including breaking down sentences into shorter paragraphs, together with increasing "white space" to improve readability (House of Commons Political and Constitutional Reform Committee 2013-14: Q.35 [Richard Heaton]).

Parliamentary Counsels' answers are quite revealing. David Cook thus states:

Over the last 20 years or so, which is the period I have been in the Parliamentary Counsel Office, there have been enormous developments in terms of the use of plain language drafting techniques to try to make legislation more accessible from the drafting perspective, and we remain very open to new ways of trying to achieve that. (ibid. Q.34)

Richard Heaton adds:

The trend has been moving away from language that looks like it has been written by a lawyer to language that might be understood by the end user. The end user is the key person in this, the person who has to use the legislation. ${ }_{56}$.... has been towards breaking ideas down, using more, as it were, editorial white space, so a sentence is broken down into paragraphs so the reader can have a clue about what is going on. There is an argument that that has gone too far and that the drawn- out nature of the statute book makes it harder to follow the story. I suppose you could say we are constantly looking for ways to present material in a way that the user can understand. But on a plain English front, just looking at the statute book from 40 years ago, we have moved a long way towards plain, simple English. We will never complete that journey. (ibid. Q.35)

This confirmation of a concern to achieve plainer language is reinforced by a recent internal guide for drafting legislation issued by Parliamentary Council which recommends the use of a considerable number of plain language techniques, including: shorter sentences, minimising cross-references, logical structure, preferring positives to negatives, using verbs rather than nouns, avoiding shall and using "familiar" words (Office of Parliamentary Counsel 2017). The claim from Parliamentary Counsel is that drafting style has embraced plain language so as to make the law understandable to the "end user." The explanatory notes to the Consumer Rights Act indicates that this aim now forms an integral part of the central purpose of the legislation, alongside reform of substantive law.

The obvious question therefore is "who is the end user"? Parliamentary Counsel see the "target audience" as depending on the context and nature of the particular legislation 
(ibid. Q.36 [Heaton]). It will include parliamentarians, the judiciary, academics and legal commentators, but also "the person without legal advice who needs to access the legislation," including a member of the general public (ibid. Q. 36 [Cook]). The evolution in legislative style, particularly apparent from 1994 and even more so in the 2015 Act, should indeed facilitate access to the legal rules for both professional and nonprofessional readers. Certainly, the use of headings in the form of questions would suggest that the non-professional audience is also being targeted. However, if the aim of the stylistic changes is the simplification of the text to make it accessible for the non-professional reader, we would argue that considerable work remains to be done to achieve this. There is much that remains complex in section 9. The section is considerably longer than previous versions, even without the rules on fitness for purpose, moved to a separate section 10. There are frequent cross-references which make reading the text an arduous task. For example, there is a cross-reference in section $9(2)(c)$ to public statements about the characteristics of goods in section 9(5), with an exception to section 9(5) introduced in a grammatically complex section 9(7). In some respects, it could even be argued that an effort to achieve plainer English has resulted in some cases in greater complexity. Thus, the exception originally stated in the opening sentence in the 1979 Act ("Except as provided by this section ...") can now be found in section 18 of the 2015 Act. The consequence is that section 9(1) is now a much plainer sentence, but a full understanding of its significance ${ }^{14}$ requires a reading of section 18, which we can suspect even an attentive reader of section 9 might omit to do. ${ }^{15}$ Section 18 also retains some of the "bad habits" of earlier versions of the legislation, notably to the extent that it starts with an exception:

18 (1) Except as provided by sections 9, 10,13 and 16, a contract to supply goods is not to be treated as including any term about the quality of the goods or their fitness for any particular purpose, unless the term is expressly included in the contract.

(2) Subsection (1) is subject to provision made by any other enactment (whenever passed or made).

Difficulty in access for the non-lawyer will also arise from the remaining complexity in the structure and terminology of the 2015 Act. There is no "overview" clause aimed to provide the reader with an initial picture as to the "story" being told. ${ }^{16}$ Although an index of contents helps the reader to navigate within the Act, the rules on quality of goods form a small part of an Act with a total of 61,000 words and 64 sections. In order to have a full understanding of the provisions on quality, it is necessary to read section 9 in the context of other provisions of the Act. Hence, the reader will need to be aware of section 1 of the Act which explains in what situations the Act applies, and of the definitions of "trader" and "consumer" in section 2. The Act also persists in using some technical legal terms: section 9(2)(b) refers to "consideration", that is the requirement of some form of exchange of benefits needed to make a contract enforceable in English law.

In addition, a person wanting to understand his rights will actually have to read much more of the Act than presented here. Section 9 describes the nature of the implied term as to quality, but what can consumers do when such a term is breached? To understand this, they will have to not only read and understand sections 1 and 2, but also sections 19 to 26 on the remedies available. Different provisions within the Act will apply if the consumer wishes to learn about her rights with respect to the sale of digital content (Chapter 3 of the Act, ss 33-47) or the provision of services (Chapter 4 of the 
Act, ss. 48-57). Indeed, one leading legal commentator observes that "this is a technical piece of legislation that is unlikely to be immediately accessible to consumers. The sections are long and detailed" (Gilliker 2017: 85).

However, more fundamentally, the very nature of legislation itself means that there are a number of obstacles to understanding for the non-professional that cannot be overcome by linguistic adjustments (Barnes 2006: 97). Indeed, Parliamentary Counsel themselves accept that there are many constraints to legislative drafting which inevitably limit the drafters' capacity to make legislation accessible to the general public (House of Commons Political and Constitutional Reform Committee 2013-14: Q.35 [Cook]). Sullivan argues that "even though legislation is addressed to the public at large, it is written for a small class of official interpreters who function as mediators between the statute book and the public."(2001:146). Assy posits that the "Plain English Movement has exaggerated the capacity of plain language to render law intelligible to non-lawyers" and that linguistic clarity is not the same thing as legal clarity (2011: 392). An obvious point is that it is insufficient to read the legislative text alone. That text is subject to interpretation by the courts and it will be difficult for the layperson to have access to court rulings, let alone understand their legal significance. Also, some degree of training will be needed to anticipate the ambiguities in the text and how the rules fit with other legal rules. As Boyd White has observed, plain language cannot overcome the very significant obstacles imposed on access by the public to legislative texts since there are "unstated conventions by which the language operates: what I call the invisible discourse of the law", whereby legal culture quickly works to turn ordinary words into legal words (1985: 63; cited in Barnes [2006: 106]). Language adjustments can make the legislation plainer to the general public, but will likely eschew in making it truly plain.

34 The approach which has been taken to the drafting of Sale of Goods legislation in fact resembles the approach suggested by Bhatia to the extent that the normative text has been "easified", with the creation of a separate simplified, non-normative, version aimed at the general public. Bhatia observes that it will often be appropriate to produce two versions of a legislative instrument: one version with normative force for the professional target audience of judges and other lawyers, and a second, simplified and non-normative version for the general public (2010: 10). He puts this as follows:

As in most technical discourses, especially those which have public implications, we need at least two versions: one for specialists, and the other for ordinary citizens. It is a common practice in sciences, where we have the original reports on experiments, and also a popular version for uninitiated readers. The two versions would serve two very different communicative purposes, one legislative, and the other informative.

Bhatia distinguishes in this way between what he refers to as "easified" and "simplified" texts. The "easified" text will be as equally authoritative as its "uneasified" predecessor, but accessibility will have been increased by the use of various "easification devices" (Bhatia 2010: 10) such as clarifying cognitive structuring by breaking down complex sentences into easier to digest phrases and paragraphs, reducing information load at specific syntactic points, avoiding excessive and nonessential nominalisations and indicating legislative intentions.

A simplified version will be aimed at non-specialists to provide them with a nonauthoritative but informative version of the legislation (Bhatia 2010: 10; Pennisi 2016: 102). A simplified version of sale of goods legislation is not to be found amongst the 
legislative sources. The 2015 Consumer Rights Act includes explanatory notes, and this has been the case for UK legislation since 1999. The explanatory notes provide a helpful summary of the Act and explain the context and reasons for the legislative rules together with their content. However, although these notes can assist in understanding the content of the Act, they do not necessarily simplify the text. Take, for example, the explanation provided for section 18 , which abounds with qualificational phrases and cross-references:

Section 18: No other requirement to treat term about quality or fitness as included 84. This section corresponds to section 14(1) of the SGA, but for contracts between a trader and consumer. The section serves to state that, unless there is an express term concerning the quality of the goods or the goods' fitness for a particular purpose, or a term implied by another enactment, the contract should not be treated as including any such terms, other than those set out in sections 9, 10, 13 and (where it applies) 16.

So where is the simplification? In fact, there is a simplified, more accessible, version of the legislation aimed at the general public but this has not been written by the UK legislative drafters. The official government website has a link to the website of an independent charity, Citizens' Advice, which includes a simplified version of the Consumer Rights Act. The task of simplification has thus been delegated to the independent charity. The text provided by Citizens' Advice provides a basic introduction to the legislation, through a very short summary and then examples of situations where the consumer would have a right to a remedy for breach of the provisions as to quality. The Citizens' Advice presentation divides the rules into clear categories which will be understandable to the consumer: "digital content", "goods bought in shops", "goods ordered at home", "services paid for in a shop", "services ordered at home".

On the page "goods bought in shops", the law is presented in figure 1. 


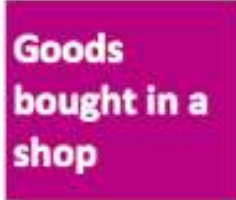

\title{
What Are Your Consumer Rights?
}

\begin{abstract}
The Consumer Rights Act $\mathbf{2 0 1 5}$ says goods must be as described, fit for purpose and of satisfactory quality. During the expected lifespan of your product you're entitled to the following:
\end{abstract}

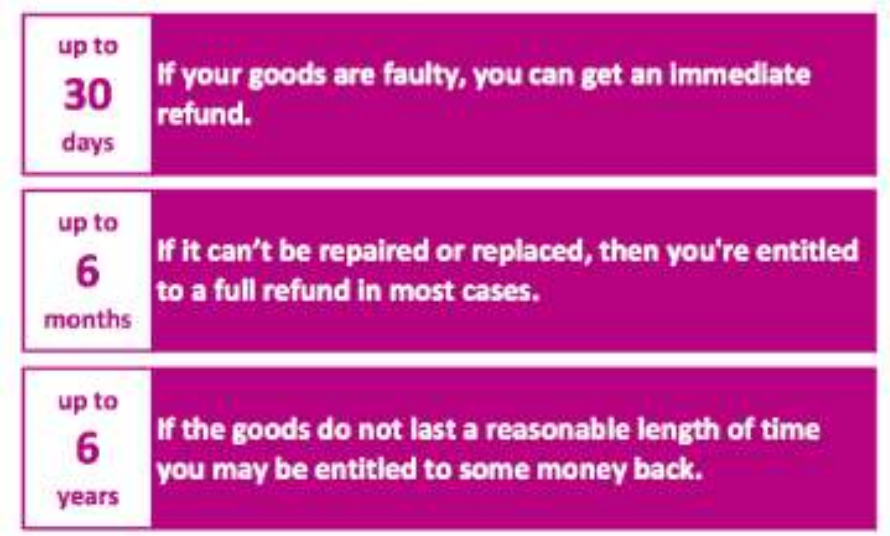

You DON'T have a legal right to a refund or replacement just because you change your mind. But... please ash us about our returns policy as we may be able to help in-store.

The information is aimed at providing the public with a broad idea of their consumer rights and remedies. The text does not explain that the rights only apply where the seller is a "trader" (so they will not apply to one-off sales), that the legislation also applies to hire purchase transactions, it does not explain either that the requirement that goods are of satisfactory quality is assessed by what a reasonable person would consider satisfactory, and it does not explain that the quality of goods includes their appearance and finish. Simplification is therefore provided at the expense of legal clarity.

\section{Conclusion}

A study of the provisions on implied terms about quality in UK sale of goods legislation from 1893 to 2015 reveals a clear and progressive evolution in legislative style. The subtle changes in favour of plainer English worked into the 1979 Act evolved into a more obvious effort at simplifying syntax, shorter sentences, plainer terms and clearer headings from 1994. Parliamentary Counsel have themselves openly acknowledged their efforts to write in plainer English, and the official explanatory notes to the Consumer Rights Act 2015 recognise this as an aim of the legislation.

However, the example of the Consumer Rights Act shows both that there is still progress to be made in making legislation plainer and that there are doubtless limits to what plain language can achieve in the legislative context. The evolution in the small corpus of legislation studied here equates more realistically to an "easification" for the professional reader than to a simplification designed to be easily accessible for the nonprofessional, but which would risk favouring simplicity over legal clarity. In the 
legislative context, where texts have a normative function, we would argue that this is an appropriate and inevitable choice.

\section{BIBLIOGRAPHY}

\section{Primary Sources}

Committee on Consumer Protection. 1962. Final Report. Cmnd 1781.

Consumer Rights Act 2015.

Citizens' Advice, Consumer Rights Act. Retrieved from <https://www.citizensadvice.org.uk/ about-us/how-citizens-advice-works/citizens-advice-consumer-work/the-consumer-rightsact-2015/> on 10/4/2018. Retrieved from <https://www.citizensadvice.org.uk/Global/Public/ Campaigns/cra/ConsumerRightsSummary-GoodsF2F.pdf> on10/4/2018.

Department for Business Innovation and Skills. 2012. Enhancing consumer confidence by clarifying consumer law. Retrieved from <https://assets.publishing.service.gov.uk/government/ uploads/system/uploads/attachment_data/file/31350/12-937-enhancing-consumerconsultation-supply-of-goods-services-digital.pdf> on 10/4/2018.

House of Commons Debates. 28 November 1979. vol.974. (HC Deb)

House of Lords Debates. 16 November 1972. vol. 336. (HL Deb)

House of Lords Debates. 10 December. 1975. vol.366. (HL Deb)

House of Commons Political and Constitutional Reform Committee. Ensuring standards in the quality of legislation, First report, session 2013-14.: Transcript of Oral Evidence. Retrieved from $<$ https://publications.parliament.uk/pa/cm201314/cmselect/cmpolcon/85/85.pdf $>$ on $12 / 4 / 2018$.

Law Commission and Scottish Law Commission. 1987. Sale and Supply of Goods, Cmnd 137, HMSO. Retrieved from <https://www.scotlawcom.gov.uk/files/8612/7989/6602/rep104.pdf> on $13 / 4 / 2018$.

Office of Parliamentary Council. UK Drafting Techniques Group. 2008. Shall. Retrieved from <http://webarchive.nationalarchives.gov.uk/20100512145311/http://www.cabinetoffice.gov.uk/ media/190076/shall.pdf> on 3/5/2018.

Office of Parliamentary Counsel. When Laws Become Too Complex. 2013. Retrieved from <https://www.gov.uk/government/publications/when-laws-become-too-complex> on 3/8/2018.

Office of Parliamentary Counsel. 2017. Drafting Guidance. Retrieved from <https:// assets.publishing.service.gov.uk/government/uploads/system/uploads/attachment_data/file/ 666328/drafting_guidance_Dec_2017.pdf> on 4/5/2018.

Renton Committee. 1975. The Preparation of Legislation. Cmnd 6053.

Sale of Goods Act 1893.

Supply of Goods (Implied Terms) Act 1973. 
Sale of Goods Act 1979.

Supply of Goods and Services Act 1982.

Sale and Supply of Goods Act 1994

UK Government website, Consumer Rights Act 2015. Retrieved from <https://www.gov.uk/ government/publications/consumer-rights-act-2015/consumer-rights-act-2015> on 10/4/2018.

\section{Secondary Sources}

Assy, Rabeea. 2011. "Can the law speak directly to its subjects? The limitation of plain language". Journal of Law and Society 38, 376-404.

BARNES, Jeffrey. 2006. "The continuing debate about Plain Language Legislation: A law reform conundrum". Statute Law Review 27, 83-132.

BenjAmin, Judah Philip \& Anthony Gordon Guest. 1981. Benjamin's Sale of Goods. 2nd edn. London: Sweet \& Maxwell.

BENTHAM, Jeremy. "Of nomography; or the art of inditing laws". In BowRING, J. (ed.), The Works of Jeremy Bentham (1843) vol.3. Edinburgh: William Tait, 231-256.

BRIDGE, Michael (ed.). 2017. Benjamin's Sale of Goods. 10th edn. London: Sweet \& Maxwell. BHATIA, Vijay K. 2010. "Drafting legislative provisions: challenges and opportunities". The Loophole, Commonwealth Association of Legal Counsel, 5-15, retrieved from <http://calc.ngo/ sites/default/files/loophole/dec-2010.pdf> on 9/5/18.

BOYD WHITE, James. 1985. Heracles Bow: Essays on the rhetoric and politics of the law. Madison: University of Wisconsin Press.

DALE, William. 1977. Legislative Drafting - a New Approach. London: Butterworths.

DALE, William. 1985. “A London particular”. Statute Law Review 6, 11-20.

DALE, William. 1992. “The European legislative scene”. Statute Law Review 13, 79-96.

GILIKER, Paula. 2017. “The Consumer Rights Act 2015 - a bastion of European Consumer Rights?”. Legal Studies 37, 78-102.

HoRN, Nick. 2011. "Legislative section headings: drafting techniques, plain language and redundancy". Statute Law Review 32,186-208.

KIMBLE, Joseph. 1992. “Plain English: a charter for clear writing.” TM Cooley Law Review 9, 1-58.

KimBLE, Joseph. 2000. “A modest wish list for legal writing”. Michigan Bar Journal 79, 1574-1577.

MACDONALD, Ros. 2004. "Plain English in the law - a new model for the twenty-first century". Commonwealth law bulletin 30, 922-947.

MELLINKOFF, David. 1963. The Language of the Law. Boston: Little, Brown.

PenNISI, Guilia Adriana. 2016. “Legislative provisions in context: A linguistic approach". Statute Law Review 37, 101-115.

RENTON, David. 1978. “The legislative habits of the British Parliament”. Journal of Legislation 5, 713.

RICHARD, Isabelle. 2006. "L'évolution de l'emploi de shall, de must et du présent simple dans le discours juridique normatif dans le cadre du Plain language movement”. ASp 49-50, 137-153. DOI: 10.4000/asp.742. 
SulLIVAN, Ruth. 2001. “Some implications of plain language drafting”. Statute Law Review 22, 145180.

TIERSMA, Peter M. 1999. Legal Language. Chicago: University of Chicago Press.

WATSON-BROWN, Anthony. 2009. "Defining 'Plain English' as an aid to legal drafting”. Statute Law

Review 30, 85-96.

WILLIAMS, Christopher. 2004. “Legal English and Plain Language: An introduction”. ESP Across

Cultures 1, 111-124.

WiLLIAMS, Christopher. 2011. "Legal English and Plain Language: An update. ESP Across Cultures 8, 139-151.

ZANDER, Michael. 2004. The Law-making Process. Cambridge: Cambridge University Press.

\section{NOTES}

1. The legislation I consider in this article applies equally in England, Wales, Northern Ireland and Scotland.

2. There are enactments introducing minor substantive changes to the provisions studied without noticeable stylistic change: The Supply of Goods (Implied Terms) Act 1973 and the Supply of Goods and Services Act 1982.

3. Defined as "an individual acting for purposes wholly or mainly outside the individual's trade, business, craft or profession". Consumer Rights Act 2015, section 2(2).

4. On the quest for precision generally in legal drafting, see Tiersma (1999: 71-86).

5. Renton traces the tendency to draft in "verbose legal jargon" back to a desire to achieve certainty in legal language from the end of the fifteenth century $(1978,7)$.

6. For a summary of the report's conclusions, see Zander (2004: 26-27).

7. Amongst the substantial literature, see Mellinkoff 1963; Kimble 1992 \& 2000; Tiersma 1999; Williams 2004; Williams 2011; MacDonald 2004; Richard 2006; Watson-Brown 2009; Bhatia 2010, Pennisi 2016.

8. The tendency to front-load legislative provisions with conditions has been attributed to the influence of George Coode, who developed guidelines on legislative drafting in the nineteenth century and argued strongly in favour of this technique, requiring all cases and conditions to be expressed first, see Watson-Brown (2009: 87).

9. A "condition" in its technical legal sense is a term which is central to the contract giving the non-breaching party the right to terminate the contract where the term is breached. A "warranty" is a minor term which does not give the right to terminate for breach.

10. Criticised by the Law Commission (1987: para. 1.15).

11. See, for example, HC Deb 28 Nov. 1979, vol.974, cc 1445-6.

12. The definition was in fact added by the 1973 Act.

13. The legislation in force is therefore still the 1979 Act, but as amended by the 1994 Act.

14. Particularly the rule now stated that a contract can specifically add additional protective terms for consumers.

15. Although unfortunately space here and the scope of this article do not permit further discussion, other choices made to simplify terminology in the Act have led to inconsistency in the terms used. See Bridge (2017 para. 14-051, 739).

16. The insertion of an overview clause is a recommendation by Parliamentary Counsel (2017: 1 ). 


\section{ABSTRACTS}

This article considers the extent to which the legislative style of sale of goods legislation in the UK has evolved from the 1893 Sale of Goods Act, through reforms in the 1970s and 1990s, to the recent Consumer Rights Act 2015. Focusing on the provisions relating to the quality of goods in sales contracts, it describes and analyses the evolution in legislative style of the different texts and considers the extent to which the development in legislative style achieves plainer language. The study reveals a progressive "easification" rather than a simplification of the legislation. The article will argue that changes in legislative style have resulted in a plainer English text that still remains difficult to access for the general public and that the task of simplifying the legislative rules for the general public has been delegated to an independent consumer rights charity.

Cet article analyse l'évolution du style des textes législatifs au Royaume-Uni portant sur la vente des biens à partir de la loi initiale de 1893. Il retrace les évolutions du style dans les réformes des années 1970 et 1990, jusqu'à la loi de 2015 sur les droits des consommateurs. L'analyse se concentre sur les dispositions relatives à la qualité des biens vendus dans les contrats de vente. L'étude examine l'évolution du style législatif dans les différents textes et se concentre sur les procédés mis en œuvre pour obtenir un style plus lisible et plus clair. L'étude du corpus met ainsi en évidence une évolution progressive vers une plus grande lisibilité de la législation. L'article explore également les limites de cette lisibilité, les textes restant difficilement abordables pour le non-initié , le travail de simplification des règles législatives ayant été délégué à une association de protection des consommateurs.

\section{INDEX}

Mots-clés: diachronie, Plain Language Movement, anglais juridique

Keywords: diachronic study, easification, Plain Language Movement, legal English

\section{AUTHOR}

\section{SIMON TAYLOR}

After a law degree from the United Kingdom, Simon Taylor obtained a doctorate in comparative law from the University Paris 1 . A former solicitor, he currently lectures at Paris Diderot University where he teaches English contract and tort law, European Union law and legal English. He is also visiting professor at the University of Louvain-la-Neuve in Belgium and the University of Bergamo in Italy. He has written widely on legal topics in international law journals and collective works and has notably published two books: Medical Accident Liability and Redress in English and French Law (Cambridge University Press 2015) and L'harmonisation communautaire de la responsabilité du fait des produits défectueux (LGDJ 1999). Simontaylor.univparis@gmail.com 